\title{
Pengembangan Bahan Ajar Menggunakan Aplikasi Kvisoft Flipbook Maker Materi Himpunan
}

\author{
Edi Wibowo ${ }^{1}{ }^{*}$, Dona Dinda Pratiwi ${ }^{1}$ \\ 1 Universitas Islam Negeri Raden Intan Lampung. Jalan Endro Suratmin, Sukarame, Bandar \\ Lampung 35133, Indonesia. \\ *Corresponding Author. Email: ediimut31@gmail.com
}

Received : 13-02-2018; Revised : 13-05-2018; Accepted : 30-05-2018

\begin{abstract}
Abstrak
Penelitian ini bertujuan untuk mengembangkan bahan ajar $e$-modul dengan menggunakan aplikasi kvisoft flipbook maker pada pokok bahasan himpunan. Untuk melihat respon guru dan peserta didik terhadap bahan ajar e-modul dengan menggunakan aplikasi kvisoft flipbook maker pada pokok bahasan himpunan. Metode pada penelitian ini dilakukan menggunakan metode Research \& Development model Borg and Gall yang telah dimodifikasi oleh Sugiyono meliputi 7 tahap yaitu: 1) Potensi dan Masalah, 2) Mengumpulkan Data, 3) Desain Produk, 4) Validasi Desain, 5) Revisi Desain, 6) Uji Coba Produk, 7) Revisi produk. Hasil dari penelitian ini menunjukan bahwa nilai kelayakan oleh ahli materi mendapat skor rata-rata 3,23 dengan kriteria baik dan nilai kelayakan oleh ahli media dengan skor rata-rata 3,28 dengan kriteria sangat baik, sedangkan nilai kelayakan oleh ahli bahasa mendapat skor rata-rata 3,02 dengan kriteria baik. Respon peserta didik sangat menarik, dngan pencapaian skor rata-rata 3,33 uji coba kelompok kecil dan pencapaian skor rata-rata 3,49 uji coba lapangan, respon uji coba guru sangat menarik dengan pencapaian skor rata-rata 3,64. Ini menunjukkan bahwa $e$ modul dengan menggunakan aplikasi kvisoft flipbook maker yang dihasilkan dalam penelitian ini dianggap layak untuk digunakan dalam pembelajaran matematika materi himpunan.
\end{abstract}

Kata Kunci: E-Modul, Kvisoft Flipbook Maker, Himpunan.

\begin{abstract}
This study aims to develop e-module teaching materials by applying kvisoft flipbook maker on the subject of the set. To view teacher and learner responses to e-module teaching materials using the kvisoft flipbook maker application on the subject of the set. The method of this research was conducted using Research \& Development method of Borg and Gall model which has been modified by Sugiyono covering 7 stages: 1) Potential and Problem, 2) Collecting Data, 3) Product Design, 4) Design Validation, 5) Design Revision, 6) Product Trial, 7) Product Revision. The results of this study indicate that the value of feasibility by the material experts scored an average of 3.23 with good criteria and value of feasibility by media experts with an average score of 3.28 with very good criteria, while the value of feasibility by linguists got a flat score 3.02 with good criteria. The response of the students was very interesting, with the achievement of the average score of 3.33 small group trials and the achievement of the average score of 3.49 field trials, the teacher's test response was very interesting with the achievement of an average score of 3.64. This shows that the e-module using the kvisoft flipbook maker application generated in this study is considered feasible for use in the mathematics learning of the set matter.
\end{abstract}

Keywords: E-Module, Kvisoft Flipbook Maker, Set. 


\section{PENDAHULUAN}

Pendidikan merupakan sarana untuk menuju kepada pertumbuhan dan perkembangan bangsa. Pendidikan juga merupakan investasi sumber daya manusia jangka panjang yang mempunyai nilai strategis bagi kelangsungan peradaban manusia di dunia (Yuliasari, 2017). Dengan pendidikan tersebut membuat manusia mengembangkan dirinya sehingga mampu menghadapi setiap perubahan yang terjadi akibat adanya kemajuan ilmu pengetahuan dan teknologi (R. W. Y. Putra \& Ruli, 2016). Maka dari itu pendidikan menjadi salah satu modal penting untuk memajukan sebuah bangsa karena kesejahteraan dan kemajuan sebuah bangsa dapat dilihat dari tingkat pendidikannya. Pendidikan memegang peranan penting dalam menciptakan individu berkualitas (Widyawati, 2016). Hal itu menyebabkan dunia pendidikan memerlukan inovasi-inovasi yang sesuai dengan kemajuan ilmu pengetahuan dan teknologi tanpa mengabaikan nilai-nilai kemanusiaan. Salah satu pendidikan yang dapat mengembangkan kemampuan, keterampilan, rasa tangung jawab serta kreatifitas adalah pendidikan matematika yang berarti didalamnya terdapat pelajaran matematika (Anggoro, 2015).

Pelajaran matematika merupakan salah satu mata pelajaran yang memiliki manfaat besar dalam kehidupan. Matematika memberikan kesempatan kepada siswa untuk melatih mental mereka dan akan berpengaruh terhadap perkembangan intelektual mereka. Melalui pelajaran matematika siswa akan mampu belajar untuk memperoleh pengetahuan secara sistematis (Ayda \& Widjajanti, 2014). Salah satu tujuan pembelajaran matematika adalah peserta didik dapat menerapkan matematika secara tepat dalam kehidupan sehari-hari serta dalam berbagai ilmu pengetahuan, guna mempersiapkan dan meningkatkan kualitas sumber daya manusia (Lanang A. K. P., Tastra, \& Suwatra, 2014). Untuk mewujudkan pendidikan Matematika yang baik, banyak sekali permasalahan yang harus diselesaikan. Seperti permasalahan dalam proses kegiatan pembelajaran. Penggunaan metode yang kurang bervariasi, kurangnya penggunaan media pembelajaran serta pembelajaran yang selalu menekankan kepada hasil belajar peserta didik tanpa memperhatikan proses belajar yang bisa menyebabkan proses pembelajaran matematika terkesan monoton dan kurang kreatif (Yulianti, Zulkardi, \& Siroj, 2010).

Begitu juga yang terjadi pada sekolah yang menjadi objek penelitian ini, penggunaan media pembelajaran belum dimanfaatkan, bahwa bahan ajar yang digunakan masih kurang menarik dan peserta didik masih sulit memahami apa yang ada di dalam bahan ajar tersebut. Sehingga peserta didik merasa bosan dengan bahan ajar yang selalu berkutat seperti itu, karena masih tergolong monoton, dan sulit dipahami. Oleh karena itu, perlu adanya inovasiinovasi dalam pembelajaran matematika agar peserta didik merasa senang dan memahami materi pelajaran pada saat pembelajaran berlangsung. Ada perbedaan tersendiri jika pembelajaran menggunakan bahan ajar atau media pemebelajaran (Masykur, Nofrizal, \& Syazali, 2017). Penulis juga memperoleh referensi bersumberkan penelitian terdahulu bahwa media pembelajaran medapat respon baik dari peserta didik (Sari, Farida, \& Putra, 2017). Supriadi, (2015) juga mengungkapkan bahwa terdapat dampak positif dari pembelajaran menggunakan bahan ajar. Sehingga peneliti tertarik untuk mengembangkan sebuah bahan ajar $e$-modul dengan 
menggunakan aplikasi kvisoft flipbook maker.

Modul adalah media atau sarana pembelajaran yang berisi materi, metode, batasan-batasan materi pembelajaran, petunjuk kegiatan pembelajaran, latihan dan cara mengevaluasi yang dirancang secara sistematis dan menarik untuk mencapai kompetensi yang diharapkan dan digunakan secara mandiri (Hamdani, 2011). Tujuan utama dari bahan ajar berbentuk modul adalah pembaca bisa menyerap materi atau bahan ajar secara mandiri (Daryanto, 2013). Menurut Prastowo, (2011), modul merupakan bahan ajar yang disusun secara sistematis dengan bahasa yang mudah dipahami agar peserta didik dapat belajar secara mandiri dengan bantuan atau bimbingan yang minimal dari pendidik. Untuk mengurangi kejenuhan mahasiswa belajar dengan modul, maka modul perlu dikombinasikan dengan media elektronik, yang sering disebut electronic module ( $e$-modul). Pembelajaran yang mendalam (deep learning) akan terwujud bila diintegrasikan dengan $e$-modul dan akan menghasilkan satu produk lulusan yang lebih baik.

Aplikasi kvisoft flipbook maker adalah salah satu aplikasi yang mendukung sebagai media pembelajaran yang akan membantu dalam proses pembelajaran karena aplikasi ini tidak terpaku hanya pada tulisan-tulisan saja tetapi bisa dimasukan sebuah animasi gerak, video, dan audio yang bisa menjadikan sebuah interaktif media pembelajaran yang menarik sehingga pembelajaran menjadi tidak monoton. Jadi $e$-modul dengan menggunakan aplikasi kvisoft flipbook maker dapat di akses secara offline dan tidak harus mengeluarkan banyak biaya karena berbentuk soft file (Susanti, 2015).
Pengembangan bahan ajar EModul ini penah dilakukan oleh peneliti sebelumnya yaitu diantaranya Andi Zulkarnain, $d k k$ perbedaan dalam penelitian ini adalah penelitian ini dilakukan dengan berbantuan WEB sehingga dilakukan secara Online namun dalam penelitian penulis hanya dilakukan penerapan E-Modul kepada siswa disekolah secara offline (Zulkarnain, Kadaritna, \& Tania, 2015). Penelitian lain dilakukan oleh Joni Susilowibowo, perbedaan dalam penelitian ini adalah aplikasi yang digunakan dalam pengembangannya yaitu penelitian ini dikembangkan dengan program aplikasi Adobe Flash CS6 sedangkan penelitian penulis dikembangkan dengan Aplikasi Kvisoft Flipbook Maker (Tania \& Susilowibowo, 2017). Penelitian lain juga dilakukan oleh Muhammad Syarif Hidayatullah, perbedaan dalam penelitian ini adalah Syarif tidak mengembangkan suatu bahan ajar $e$-modul tetapi mengembangkan media pembelajaran berbasis Kvisoft Flipbook Maker, sedangkan penelitian penulis yaitu mengembangkan bahan ajar $e$-modul dengan aplikasi Kvisoft Flipbook Maker (Hidayatullah \& Rakhmawati, 2016). Kemudian penelitian selanjutnya yaitu dilakukan oleh Abdul Ghofur dan Rudy Kustijono, perbedaan pada penelitian ini adalah bahan ajar dan materi yang diberikan, pada penelitian ini bahan ajar yang dikembangkan adalah $e$-book pada materi kinematika gerak lurus sedangkan penelian penulis mengembangkan bahan ajar $e$-modul dengan materi himpunan (Ghofur \& Kustijono, 2015).

Berdasarkan penelitian terdahulu yang relevan tersebut terdapat perbedaan dan pembaharuan dari setiap penelitian yang dilakukan. Perbedaan dan pembaharuan dalam penelitian ini terletak pada penggunaan aplikasi kvisoft flipbook maker sebagai 
alat bantu untuk membuat $e$-modul. Tujuan dari penelitian ini adalah untuk mengembangkan bahan ajar $e$-modul dengan menggunakan aplikasi kvisoft flipbook maker dan mengetahui bagaimana respon pendidik atau guru serta respon peserta didik berkaitan dengan $e$-modul yang akan dikembangkan.

\section{METODE PENELITIAN}

Penelitian ini menggunakan metode penelitian dan pengembangan (research and Development). Model pengembangan yang digunakan dalam penelitian ini adalah model Borg and Gall. Sugiyono menjelaskan ada 10 langkah tahapan langkah dari Borg and Gall (Sugiyono, 2011). Namun karena keterbatasan peneliti dalam penelitiannya hanya menggunakan 7 tahap dari 10 tahap yang ada. Menurut Ardhana, setiap pengembangan tentu saja dapat memilih dan menentukan langkah-langkah yang paling tepat bagi dirinya berdasarkan kondisi khusus yang dihadapainya (Haryanto, Dwiyogo, \& Sulistyorini, 2015). Tahapan itu diantaranya:

1. Potensi dan Masalah

2. Mengumpulkan Data

3. Desain Produk

4. Validasi Desain

5. Revisi Desain

6. Uji Coba Produk

7. Revisi produk

Teknik analisis data yang digunakan dalam penelitian ini adalah teknik analisis deskriptif kualitatif yang memaparkan hasil pengembangan produk yang berupa bahan ajar $e$-modul dengan menggunakan aplikasi kvisoft flipbook maker.

Tabel 1. Skor Penilaian Validasi Ahli

\begin{tabular}{ll}
\hline Skor & Kriteria \\
\hline 4 & Sangat Baik \\
3 & Baik \\
2 & Kurang Baik \\
1 & Sangat Kurang Baik \\
\hline
\end{tabular}

Data yang diperoleh dari angket yang diberikan dianalisis menggunakan statistik deskriptif kualitatif. Hasil dari skor penilaian dari masing-masing validator tersebut kemudian dicari rataratanya dan dikonverensikan ke pertanyaan untuk menentukan kevalidan dan kelayakan bahan ajar $e$ modul dengan menggunakan aplikasi kvisoft flipbook maker.

Tabel 2. Kriteria validasi

\begin{tabular}{cl}
\hline Skor Kualitas & Kriteria Kelayakan \\
$3,26<\bar{x} \leq 4,00$ & Valid \\
$2,51<\bar{x} \leq 3,26$ & Cukup Valid \\
$1,76<\bar{x} \leq 2,51$ & Kurang Valid \\
$1,00<\bar{x} \leq 1,76$ & Tidak Valid \\
\hline Instrumen & yang digunakan
\end{tabular}
memiliki 4 jawaban, sehingga skor penilaian total dapat dicari dengan menggunakan rumus sebagai berikut:

$$
\bar{x}=\frac{\sum_{i=1}^{n} x_{i}}{n}
$$

Dengan

$$
x_{i}=\frac{\text { Jumlah skor }}{\text { Skor maks }} \times 4
$$

Keterangan:

$\bar{x}=$ Rata-rata akhir

$x_{i}=$ Nilai uji operasional angket setiap peserta didik

$n$ = Banyaknya peserta didik yang mengisi angket

\section{HASIL DAN PEMBAHASAN}

Hasil pengembangan yang dilakukan oleh peneliti ini adalah menghasilkan Bahan ajar E-Modul dengan menggunakan aplikasi kvisoft flipbook maker. Penelitian dan pengembangan ini dilakukan dengan menggunakan prosedur pengembangan menurut sugiyono yang dilakukan dari tahap 1 hingga tahap 7.

Pada tahap yang pertama adalah tahap potensi dan masalah. Potensi 
Desimal, 1 (2), 2018 - 151

Edi Wibowo, Dona Dinda Pratiwi

dalam penelitian ini adalah mengembangkan bahan ajar e-modul dengan menggunakan aplikasi kvisoft flipbook maker. Penelitian ini dilakukan di sekolah yang cukup mumpuni dalam hal sarana dan prasarananya, tetapi sarana dan prasarana yang ada tidak dimanfaatkan dengan maksimal, sehingga peneliti ingin mengembangkannya.

Dari tahap potensi dan masalah kemudian peneliti mengumpulkan informasi yang berkaitan dengan kendala-kendala yang ada pada sekolah tersebut. Peneliti juga mewamewawancarai salah satu guru matematika dan peserta didik serta mengumpulkan buku, materi dan jurnal yang berkaitan dengan Modul.

Sekiranya informasi yang telah didapat cukup banyak maka peneliti melakukan desain produk. Dalam tahap desain produk pengembangan $e$-modul dengan menggunakan aplikasi kvisoft flipbook maker. Langkah-langkah penyusunan desain produk $e$-modul ini, diantaranya adalah menyesuaikan standar kompetensi dan kompetensi dasar serta silabus berdasarkan kurikulum K13.

Selanjutnya untuk tahap berikutnya yaitu validasi desain $e$ modul. Validasi $e$-modul dengan menggunakan aplikasi kvisoft flipbook maker dilakukan oleh 9 ahli, yang terdiri dari 3 ahli materi, 3 ahli media, dan 3 ahli bahasa. Berdasarkan penilaian validasi ahli materi dianalisis 2 aspek yaitu aspek kelayakan isi dan aspek kebahasaan. Pada penilaian validasi ahli media dianalisis 2 aspek yaitu aspek kegrafikan dan kebahasaan sedangkan validasi ahli bahasa hanya memiliki 1 aspek yaitu aspek kebahasaan.

Hasil validasi oleh ahli materi pada produk yang disajikan dalam bentuk grafik berikut:

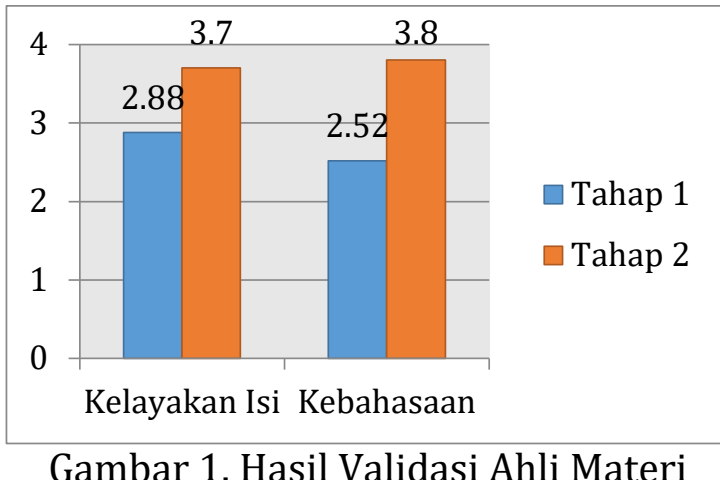

Berdasarkan Gambar 1 terlihat bahwa, terjadi peningkatan yang sangat signifikan dari tahap 1 ke tahap 2, baik pada aspek kelayakan isi dengan selisih 0,82 maupun pada aspek kebahasaandengan selisih 1,28.

Validasi selanjutnya yaitu validasi ahli media, hasil validasi oleh ahli media pada produk disajikan dalam bentuk grafik berikut:

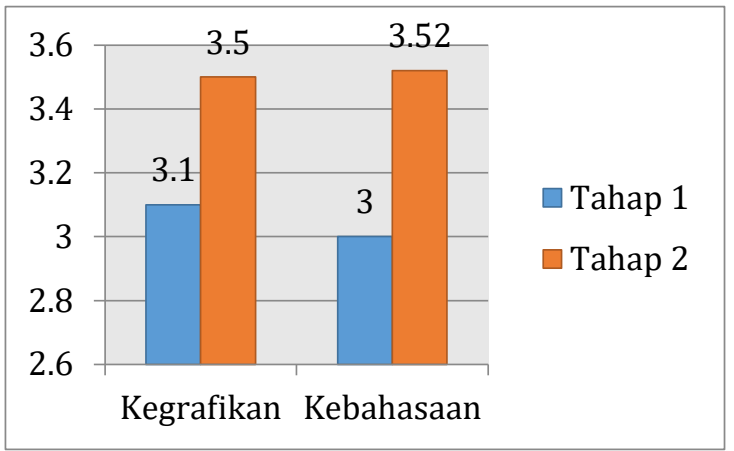

Gambar 2. Hasil Validasi Ahli Media

Berdasarkan Gambar 2, grafik perbandingan hasil validasi ahli media menunjukkan peningkatan dari tahap 1 ke tahap 2, baik pada aspek kegrafikan dengan selisih peningkatan 0,4 maupun aspek kebahasaan dengan selisih 0,52.

Kemudian untuk vakidasi yang terakhir yaitu validasi ahli bahasa, hasil validasi oleh ahli bahasa pada produk disajikan dalam bentuk grafik berikut: 
Desimal, 1 (2), 2018 - 152

Edi Wibowo, Dona Dinda Pratiwi

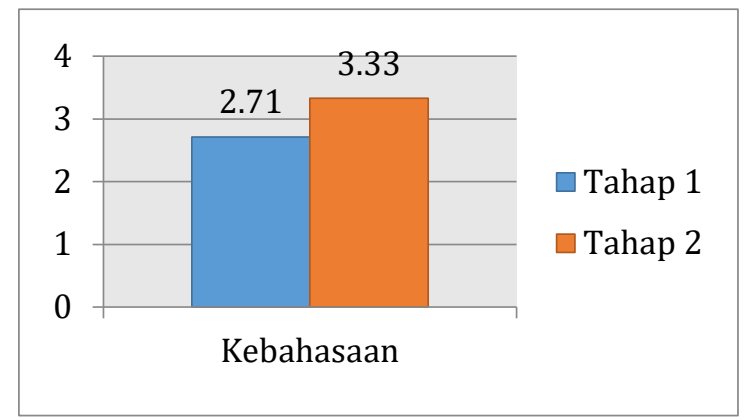

Gambar 3. Hasil Validasi Ahli Bahasa

Terlihat dari Gambar 3, menunjukkan bahwa perbandingan validasi ahli bahasa pada tahap 1 ke tahap 2 mengalami peningkatan yang signifikan yaitu dengan selisih peningkatan sebesar 0,62.

Setelah desain produk divalidasi melalui penilaian dari ahli materi, ahli media, dan ahli bahasa serta guru matematika. Peneliti melakukan revisi terhadap desain produk yang dikembngkan berdasarkan saran atau masukan yang diberikan oleh para ahli.

Saran atau masukan oleh ahli materi yaitu salah satunya dapat dilihat pada gambar berikut:
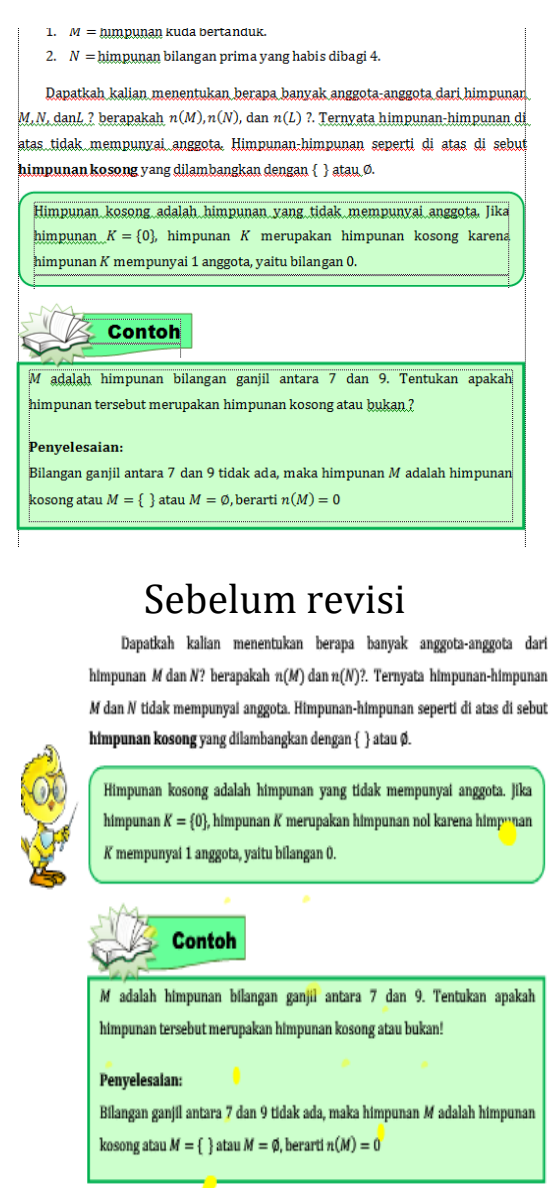

Sesudah revisi

Gambar 4. Perbaikan himpunan nol

Berdasarkan Gambar 4, menjelaskan bahwa validator ahli materi menyarankan untuk menambahkan definisi tentang himpunan nolserta perbedaannya dengan himpunan kosong. Setelah perbaikan, saran dan masukan validator ahli materi telah dilaksanakan.

Kemudian saran dari validasi ahli media yang harus diperbaiki yaitu sebagai berikut: 
Desimal, 1 (2), 2018 - 153

Edi Wibowo, Dona Dinda Pratiwi

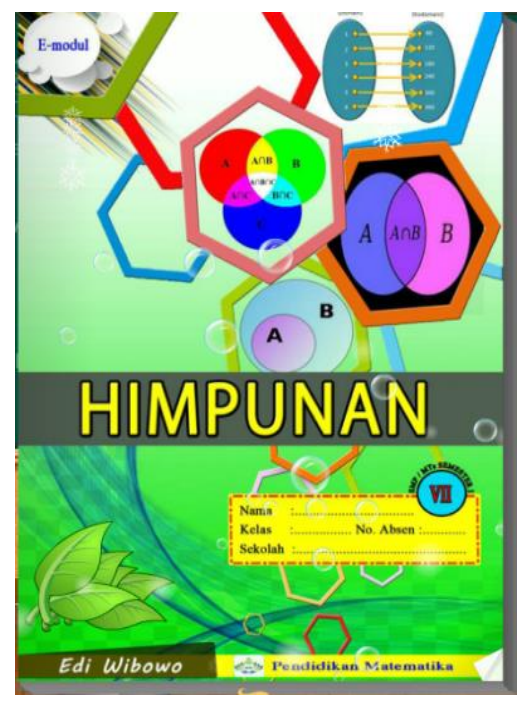

Sebelum revisi

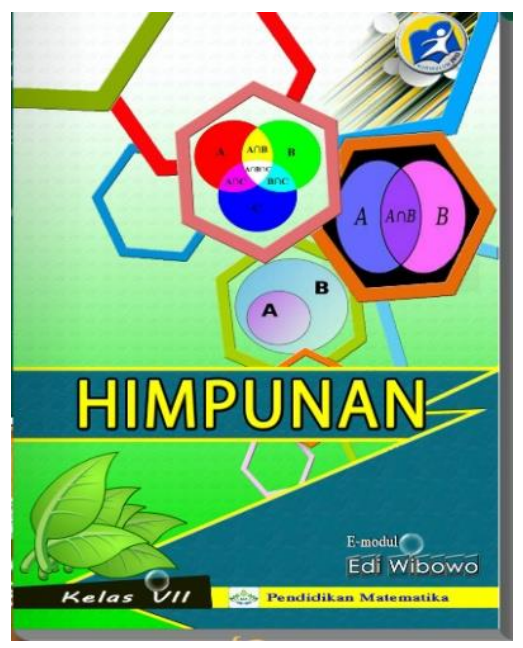

Sesudah revisi

Gambar 5. Perbaikan cover depan $e$ modul

Terlihat pada Gambar 5, perbaikan dilakukan karena cover $e$-modul pada produk awal pengembangan tidak mencantumkan kurikulum 2013, serta masih tercantum kolom nama peserta didik, sedangkan pada modul pembelajaran berbeda dengan LKS. Untuk modul tidak tercantum kolom nama sedangkan untuk LKS tercantum kolom nama peserta didik. Oleh karena itu dilakukan perbaikan sesuai saran dari validator ahli media agar lebih baik dan sesuai dengan kurikulum yang dipakai pada pendidikan tahun ini sehingga dapat menarik minat belajar peserta didik.

Kali ini kita bahas saran dari ahli bahasa salah satunya sebagai berikut:

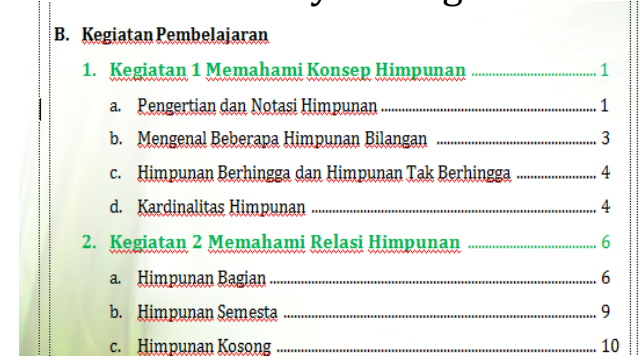

Sebelum revisi

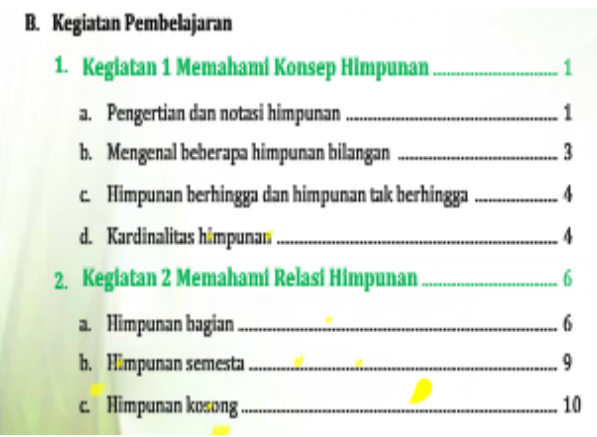

Sesudah revisi

Gambar 6. Perbaikan penulisan sesuai PUEBI

Berdasarkan Gambar 6 dilakukan perbaikan penulisan kalimat agar lebih efektif dan menggunakan PUEBI yang benar. Perbaikan penulisan harus dilakukan karena penulisan belum sesuai dengan PUEBI, pada produk awal $e$-modul bahasa yang digunakan kurang efektif. Validator menyarankan untuk mengubah kalimat agar lebih efektif sehingga dilakukan perbaikan pada penulisan dan penggunaan bahasa.

Setelah produk melalui tahap validasi oleh ahli materi, ahli media dan ahli bahasa serta telah selesai diubah, selanjutnya produk diujikan dengan uji coba kelompok kecil yang terdiri 10 peserta didik, dan uji coba kelompok besar yang terdiri dari 30 peserta didik. Uji coba ini dilakukan dengan cara memberikan angket untuk mengetahui 
kemenarikan produk. Uji coba dilakukan 2 tahap yaitu uji coba kelompok kecil dan uji coba lapangan dengan melibatkan 10 peserta didik untuk uji coba kelompok kecil dan 30 peserta didik untuk uji coba lapangan dengan cara memberi angket untuk mengetahui respon peserta didik terhadap kemenarikan bahan ajar $e$-modul. Uji coba dilakukan dapat dilihat talam tabel berikut.

Tabel 3. Uji coba kelompok kecil

\begin{tabular}{ll}
\hline Skor rata-rata & Kriteria \\
3.33 & Sangat Menarik \\
\hline
\end{tabular}

Tabel 4. Uji coba Lapangan

\begin{tabular}{ll}
\hline Skor rata-rata & Kriteria \\
3.49 & Sangat Menarik \\
\hline
\end{tabular}

Berdasarkan Tabel 3 dan Tabel 4, hasil uji coba produk sudah mencapai kriteria sangat menarik, hal ini berarti bahan ajar $e$-modul yang dikembangkan oleh penulis mempunyai kriteria Sangat Layak digunakan sebagai alat bantu dalam kegiatan belajar mengajar pada materi himpunan. Hasil penelitian ini sama dengan hasil penelitian yang dilakukan oleh Joni Susilowibowo dengan hasil media pembelajaran dengan pengembangan E-Modul mendapatkan respon yang sangat menarik oleh peserta didik, selain itu EModul yang dikembangkan layak digunakan sebagai bahan ajar. Selain itu penelitian ini sama dengan hasil penelitian oleh Komang, dkk bahwa pembelajaran dengan E-Modul mendapatkan respon yang lebih disukai oleh siswa dibandingkan dengan pembelajaran dengan buku ajar dan metode konvensional (K. W. B. Putra, Wirawan, \& Pradnyana, 2017). Selanjutnya bahan ajar $e$-modul ini dapat dimanfaatkan sebagai salah satu sumber belajar bagi peserta didik dan guru di SMP/MTs pada materi himpunan untuk kelas VII.

\section{SIMPULAN DAN SARAN}

Bahan ajar $e$-modul dengan menggunakan aplikasi kvisoft flipbook maker yang dihasilkan telah dikembangkan dengan model Borg and Gall yang dimodifikasi oleh Sugiyono. Kemudian validasi dilakukan oleh ahli materi, ahli media dan ahli bahasa diperoleh nilai rata-rata dengan kriteria sangat baik. Respon guru dan peserta didik terhadap $e$-modul dengan menggunakan aplikasi kvisoft flipbook maker diperoleh nilai rata-rata skor masing-masing 3,64 dan 3,49 dengan kriteria sangat menarik. Terlihat dari hasil penilaian para ahli dan respon guru maupun peserta didik sangat memuaskan, maka $e$-modul dengan menggunakan aplikasi kvisoft flipbook maker yang dihasilkan dianggap layak untuk digunakan dalam pembelajaran matematika materi himpunan.

Senada dengan kesimpulan pada penelitian ini, juga terdapat saran atau masukan dari para ahli, yaitu: bahan ajar $e$-modul dengan menggunakan aplikasi kvisoft flipbook maker ini perlu ditingkatkan kembali menjadi e-learning dengan berbantuan intenet agar mudah diakses dan bisa di buka pada smartphone maupun tablet. Kemudian gunakan versi baru kvisoft flipbook maker yang memuat animasi, gambar yang berkaitan dengan materi yang diberikan.

\section{DAFTAR PUSTAKA}

Anggoro, B. S. (2015). Pengembangan Modul Matematika Dengan Strategi Problem Solving untuk Mengukur Tingkat Kemampuan Berpikir Kreatif Matematis Siswa. Al-Jabar: Jurnal Pendidikan Matematika, 6(2), 122-129.

Ayda, E., \& Widjajanti, D. B. (2014). Pengembangan perangkat pembelajaran teorema pythagoras dengan media berbantuan komputer. Jurnal Riset Pendidikan 
Matematika, 1(2), 216-226.

Daryanto. (2013). Media Pembelajaran. Bandung: Satu Nusa.

Ghofur, A., \& Kustijono, R. (2015). Pengembangan e-book Berbasis Flash Flipbook pada Materi Kinematika Gerak Lurus Sebagai Sarana Belajar Siswa SMA Kelas X. Jurnal Inovasi Pendidikan Fisika (JIPF), 4(2), 176-180.

Hamdani. (2011). Strategi Belajar Mengajar. Bandung: Pustaka Setya.

Haryanto, T. S., Dwiyogo, W. D., \& Sulistyorini. (2015). Pengembangan Pembelajaran Permainan Bolavoli Menggunakan media Interaktif di SMP Negeri 6 Kabupaten Situbondo. Jurnal Pendidikan Jasmani, 25(1), 123-128.

Hidayatullah, M. S., \& Rakhmawati, L. (2016). Pengembangan Media Pembelajaran Berbasis Flipbook Maker pada Mata Pelajaran Elektronika Dasar di SMK N 1 Sampang. Jurnal Pendidikan Teknik Elektro, 5(1), 83-88.

Lanang A. K. P., I. G., Tastra, I. D. K., \& Suwatra, I. G. N. I. W. (2014). Pengembangan Media Video Pembelajaran dengan Modl ADDIE pada Pembelajaran Bahasa Inggris di SDN 1 Selat. E-Jurnal Edutech Universitas Pendidikan Ganesha, 2(1).

Masykur, R., Nofrizal, N., \& Syazali, M. (2017). Pengembangan Media Pembelajaran Matematika dengan Macromedia Flash. Al-Jabar: Jurnal Pendidikan Matematika, 8(2), 177185.

Prastowo. (2011). Panduan Kreatif Membuat Bahan Ajar Inovatif. Yogyakarta: DIVA Pers.

Putra, K. W. B., Wirawan, I. M. A., \& Pradnyana, G. A. (2017). Pengembangan e-Modul Berbasis Modul Pembelajaran Discovery Learning pada Mata Pelajaran "Sistem Komputer" untuk Siswa
Kelas X Multimedia SMK Negeri 3 Singaraja. Jurnal Pendidikan Teknologi Dan Kejuruan, 14(1), 4049.

Putra, R. W. Y., \& Ruli, A. (2016). Pengembangan Bahan Ajar Materi Trigonometri Berbantuan Software iMindMap pada Siswa SMA. AlJabar: Jurnal Pendidikan Matematika, 7(1), 39-47.

Sari, A. U., Farida, \& Putra, F. G. (2017). Pengembangan Media Pembelajaran Berbantuan Web Dengan Pendekatanangun Ruang Sisi Datar. In Seminar Nasional Matematika dan Pendidikan Matematika 2017 (pp. 209-214).

Sugiyono. (2011). Metode Penelitian Kuantitatif Kualitatif dan $R \& D$. Bandung: Alfabeta.

Supriadi, N. (2015). Mengembangkan Kemampuan Koneksi Matematis Melalui Buku Ajar Elektronik Interaktif (BAEI) yang Terintegrasi Nilai-Nilai Keislaman. Al-Jabar: Jurnal Pendidikan Matematika, 6(1), 63-73.

Susanti, F. (2015). Pengembangan EModul dengan Aplikasi Kvisoft Flipbook Maker pada Pokok Bahasan Fluida Statis untuk Peserta Didik SMA/MA Kelas X. Repository UIN Sunan Kalijaga Yogyakarta.

Tania, L., \& Susilowibowo, J. (2017). Pengembangan Bahan Ajar e-Modul Sebagai Pendukung Pembelajaran Kurikulum 2013 pada Materi Ayat Jurnal Penyesuaian Perusahaan Jasa Siswa Kelas X Akuntansi SMK Negeri 1 Surabaya. Jurnal Pendidikan Dan Akuntansi, 1, 1-9.

Widyawati, S. (2016). Pengaruh Kemampuan Koneksi Matematis Siswa terhadap Prestasi Belajar Matematika Ditinjau dari Gaya Belajar pada Materi Bangun Ruang Sisi Datar Siswa Kelas IX SMP di Kota Metro. Iqra': Jurnal Kajian Ilmu Pendidikan, 1(1), 47-68. 
Desimal, 1 (2), 2018 - 156

Edi Wibowo, Dona Dinda Pratiwi

Yulianti, E., Zulkardi, \& Siroj, R. A. (2010). Pengembangan Alat Peraga Menggunakan Rangkaian Listrik Seri-Paralel untuk Mengajarkan Logika Matematika di SMK Negeri 2 Palembang. Jurnal Pendidikan Matematika, 4(1).

Yuliasari, E. (2017). Eksperimentasi Model PBL dan Model GDL Terhadap Kemampuan Pemecahan
Masalah Matematis Ditinjau dari Kemandirian Belajar. Jurnal Ilmiah Pendidikan Matematika (JIPM), 6(1), 1-10.

Zulkarnain, A., Kadaritna, N., \& Tania, L. (2015). Pengembangan e-Modul Teori Atom Mekanika Kuantum Berbasis WEB dengan Pendekatan Saintifik. Jurnal Pendidikan Dan Pembelajaran Kimia, 4(1), 222-235. 